\title{
DOCUMENTOS
}

\section{Poemas de L. Lugones en la Revista Moderna de México}

La poesía de Leopoldo Lugones se difundió en México desde finales del siglo pasado. $Y$ ya en nuestro siglo abundan los textos lugonianos, en prosa y en verso, en diarios y revistas de la capital mexicana y del interior del país. Asimismo abundan las imitaciones, pastiches, dedicatorias elogicsas al poeta y juicios que llegan a la exaltación valorativa de poetas como Rafael López, J. J. Tablada, Ramón López Velarde y Alfonso Reyes, por sólo citar a los más conocidos. ${ }^{1}$ Lugones fue consecuente con este aprecio de la joven generación de poetas mexicanos, como lo prueban sus prólogos poéticos a Oro y negro de Francisco $M$. de Olaguíbel y a Al sol y bajo la luna de José Juan Tablada. ${ }^{2}$ En un trabajo que preparamos sobre "Leopoldo Lugones en México" daremos cuenta detallada de esta difusión mexicana del poeta argentino. Ahora sólo queremos adelantar dos sonetos y un poema de Lugones publicados en la Revista Maderna, en 1898, textos que fueron hallados por Ernesto Mejía Sánchez y entregados al autor de esta nota para su publicación en la Revista Iberoamericana, por no hallarse recopilados en las Obras poéticas completas de la edición Aguilar. Agregamos otro poema, "El sepulcro de los cóndores", hallado por nosotros, cuya redacción debe ser de la misma época de los anteriores, pero que fue publicado en la Revista Móderna de México en I908. Tampoco figura en la edición citada.

AlFredo A. Roggiano

University of Pittsburgh 


\section{[DOS] SONETOS PARA MAYOR HONRA DEL ARTE Y CONDENACION DE "ALGUNOS"}

\section{[I]}

Es roja la risa y es brava la risa latina:

así una ebria rosa querida del viejo Pirrón.

La púrpura pide celosa custodia a la espina.

¡Oh dulces abejas aquellas del agrio aguijón!

¡La cóncava oreja del asno sapiente culmina!

$\mathrm{Su}$ bronca laringe respinga con trágico son

los hipos feroces mojados de baba dañina, su vientre interrumpe la noble función digestión.

Porque oye las trompas que esfuerzan sus voces de plata, los claros relinchos de acero de la cabalgata que trae la fama de un triunfo magnífico y cruel; y siente en los cepos de hierro crujir sus rodillas, y alzarse vibrando por sobre sus rotas costillas con mágico imperio la vara de un verde laurel.

La gloria de un casco surgiendo del Alba serena.

El cuello de un potro que encrespa su bélica crin.

La punta de un sable más limpio que una azucena.

El ala de un águila abierta sobre un paladín.

Hollando las nubes de sangre que cubren la escena con sus pies de oro, levántase un gran serafín; y sobre la noche que encoge sus alas, resuena la lengua soberbia que tiene el metal del clarín.

Ese es el Cruzado del Arte que trae su trompa. Su escudo es un astro: Orión o Arturo o Sahil. El sol del Oriente le cubre de fuego y de pompa. El ojo del Aguila adorna su fiero perfil. 


\section{Envio}

$\mathrm{El}$ arte es el nuestro! Su lirio imperial condecora la noble coraza del fiel paladín de la Aurora.

\section{LEOPOLDO LUGONES}

Revista Moderna, México, año I, No. 3 , $I^{9}$ de septiembre de 1898 , p. 47 .

\section{TAPIZ DUCAL}

Ampliando las alas en un arco sonoro, la hermosa cola abierta cual panoplia oriental cruzada de mil sables con límpidos puños de oro, bajo el negro eukaliptus está un pavo real.

La inmensa emoción pálida de una tarde de rosa tiembla sobre las nubes solemnes de esplendor, y soberbiamente ebria la lascivia orgullosa, como un Sultán el pájaro glorifica su amor.

Hay una joven blanca, que es una joven bella; sueña en los moribundos éxtasis de la luz. Tal vez sea tan blanca el alma de una estrella, tal vez sea tan bella una perla de Ormuz.

Sueña un amor de príncipe; intenso aroma exhala cual brasa de incensario, su boca de carmín, El pájaro se acerca y roza con su ala la gala de la falda de crujiente, satín.

$Y$ el amoroso pico en la boca entreabierta se guarece buscando deleites de embriaguez... Ved cómo la doncella contempla el ave muerta de amor, las alas regias tendidas a sus pies.

\section{LEOPOLDO LUGONES}

Revista Moderna, México, año I, No. 8, I5 de noviembre de I898, p. $\times 28$. 


\section{EL SEPULCRO DE LOS CONDORES}

Desde el peñón, la vista derramada a lo lejos, contempla, fantaseado por celajes bermejos, un agreste dominio de rocas y tallares;

la fronda que abre sólo paso a la res arisca, es numerosa como las aguas de los mares; y sobre los truncados bastiones de arenisca, que el manantial salvaje con su arabesco labra, pace una híspida hierba tal cual nudosa cabra. Enarbola el coriáceo nopal su brava penca en el talud que eriza de cilicio la zarza; y bajo la pantalla de bambú que lo engarza cual ojo paralítico brilla un lago en su cuenca.

Más allá el sol, ya hundido, confunde en su agonía, que orla de taciturno crespón los horizontes, en palpitante caos las nubes y los montes, bajo una gigantesca luz de cosmogonía.

Con gracia casi lánguida, una emoción secreta conmueve aquel paisaje que el silencio completa como una alma. La tarde cuchichea un augurio con su brisa, en un escalofrío de mercurio, infundiendo a las cosas esa cordial molestia bajo la cual se agobia la cabizbaja bestia, y que espiritualiza tan extrañas congojas en el desasosiego tímidu de las hojas.

Por el cenit que ahonda la ilusión vespertina, flota un cóndor inmóvil, de vuelta a la morada, $y$ en su silueta negra y aguda se imagina el vibrante equilibrio de una aguja imantada; abajo, discerniendo los claros de la breña, mira los parapetos natales de su peña; el lago, el sol, la rampa donde se azora el corzo, y con breve aletazo que en instantáneo escorzo del sol, lo dora, a su ámbito montañés se aproxima. Rosando, vuelta a vuelta, la hondonada y la cima, 
en ebriedad de espacio su descenso posterga; el viento zumba en su ala como en un alta verga; su vuelo cruza en largos soslayos de navaja; y cuando a breve techo de su páramo baja, con la emcción sanguínea de un ímpetu bizarro, vibra la cresta en su áspera cabeza de guijarro y una feroz codicia, que es paternal desvelo, en la vívida gota de su ojo centellea.

Pronta a los habituales estímulos de cielo, la prole, ya magnífica en su imperial ralea, ensaya los ineptos muñones, y su buche hace estallar en píos el énfasis de un hipo. Del flojel que la felpa con tibiezas de estuche, su lampiña cabeza surge en su extraño tipo que a una zurda ironía mezcla un altivo ceño; la inexpugnable grieta que cobija su sueño, exhala un olor flavo, como un cubil felino.

A la glacial frescura que acera el aire andino, el hambre sanguinaria devora esos capullos de fiera, que en airada confusión de murmullos, preguntan en las nubes toras anatomias, de tegumentos cárdenos y cruencias bravías; $y$ ante el sol agrupado sobre sus parapetos, le gesticulan mimos como si fueran nietos.

El crepúsculo, en tanto, gana las cumbres solas, proyectando a las nubes, en acuarelas tiernas, ese angélico rosa de las nieves eternas que conoce el heráldico armiño de las golas. Forjando algún antiguo tecuerdo cinegético en desdeñosas grietas, un viejo buitre, hermético cual un coleóptero, alza su bloque monolito que arraiga en el peñasco la zarpa ahora inerme, $y$ ante el flameado cielo diríase que duerme, ahito de montaña y hastiado de infinito. Corsario de la ráfaga, el cielo fue su lente, y las nubes su tálamo de luz, y el sol ponienté que dilataba la inmensidad, su candelabro, 
a cuya luz suprema, tendido el cuello glabro, mientras ya era de noche sobre toda llanura, prolongaba sus tardes a diez mil pies de altura. En soledad huraña sobre su cordillera, un procelario anhelo lo asalta ante la hoguera del ocaso, que en pólvoras de bermellón deflagra, y adobando de fuerza su carne bruna y magra, vuelve a su ser decrépito la pasión de la fiera, El volador desciende con crujidos de brusco Abanico, muy cerca del ríspido pedrusco Que el viejo cóndor tiene de pedestal. Su prole, cuyo voraz insomnio coronaba la mole, bajo el paterno buche se agolpa, pía y bufa, y alzándose hasta el ampo de la viril corbata, hormiguean las negras cabecitas de trufa...

Mas sordo a su bravía tribu, el joven pirata, junto al sombrío abuelo pliega su doble foque, un sobresalto invade la inercia de aquel bloque; los cuellos se entrelazan, y sobre el hosco cerro, cuya breña la noche con sus sombras intrinca ante el sol, que prolonga desolaciones de Inca-; trábanse los dos picos en ósculo de hierro.

LEOPOLDO LUGONES

Revista Moderna de México, Vol. XI, No 2, r9o8, pp. I40-I42. 